\title{
Imposing Biopores in Agroforestry as an Alternative Measure of Climate Adaption in Semi-Arid Tropic of Eastern Indonesia
}

\author{
Muhamad Husni Idris ${ }^{1,3^{*}} \quad$ Mahrup $^{2,3}$ \\ 1. Depart. of Forest Science, Mataram University, J1 Pendidikan 37 Mataram Lombok Indonesia, 83125 \\ 2. Depart. of Soil Science, Mataram University, Jl. Majapahit 62 Mataram Lombok, Indonesia 83125 \\ 3. Research Center for Water Resource and Agroclimate, Mataram University, J1 Pendidikan 37 Mataram \\ Lombok Indonesia, 83125 \\ * E-mail of the corresponding author: husni_id@yahoo.com, puslisda@gmail.com
}

\begin{abstract}
A small scale agroforestry model integrated with land and water conservation was scientifically tested to alleviate drought impact in dry land agriculture in North Lombok. Biopores were imposed to the model as an integrated approach in climate change adaptation. Northern part of Lombok is typologically less developed soils with high erosion, undulating, and under semi-arid climate is vulnerable to climate change. Measures of adaptation in such ecosystem should be carried out by (i) implementing best practice in land and water conservation, (ii) applying appropriate cropping system, (iii) considering local climate variability and (iv) using water efficiently as economic goods. These four components were incorporated in a scenario of small scale agroforestry. A participatory action research with three field experiments were conducted at Sukadana village, sub-district of Bayan, North Lombok. Some factors were imposed in the scenario, namely: (1) composted biopores of diameter $10 \mathrm{~cm}$ and $20 \mathrm{~m}$ depth, on farms and $40 \mathrm{~cm}$ depth, underneath of trees pit, (2) alley cropping in agroforestry, (3) characterization of local climate, and (4) water use efficiency. Three groups of farmers were selected by means of a purposive sampling to involve in two consecutive years of field experiments, i.e. 2012 and 2013. Output of research was a model of small scale agroforestry integrating cropping system, land and water conservation, as well as local climate characteristic. The model performed a significant contribution on improving performance and yields of agricultural crops as well as wood trees, mainly white teak (Gmelina arborea) growing well on biopores. Biopores underneath trees reduced water and soil particles loss through runoff, as well as increased carbon sequestrated. On farm lands biopores played a significant role in conserving soil moisture, increasing crop water use efficiency and providing essential nutrient for plants. Conserved water could be used by plants in a period of dry spell to avoid drought stress. The imposed biopores in agroforestry could be an adaptation measure to climate variability, and climate change on farm level in semi arid tropic of eastern Indonesia.
\end{abstract}

Keywords: water conservation, biopores, agroforestry and climate variability

\section{Introduction}

There is no simple recipe for success in developing techniques or model to suit each particular situation for climate change adaptation (IPCC 2007). Agroforestry is one of possible integrated measures which combine trees, and shrubs with agriculture crops and /or livestock. These combination create more diverse, productive, profitable, healthy and sustainable land-use systems (Kang 2000; Alao et al 2013), and it has been considered as useful applications in arid and semi-arid regions for soil reclamation rehabilitation (Acharya et al 2014; Kumar 2013 )

In seasonally dry and tropical region at lower latitudes, crop productivity is projected to decrease for even small local temperature increase by $1^{\circ}$ to $2^{\circ} \mathrm{C}$ (Easterling et al 2007; Porter et al 2014). Current research conducted in Lombok, Eastern Indonesia (Ministry of Environment 2011) concluded that average temperature in Lombok will increase by $1^{\circ}$ in 2030 's, while nowadays it increases by $0.5^{\circ} \mathrm{C}$ during wet months. Therefore, agroforestry along with management practices in soil and water conservation are important to succeed in climate change adaptation.

Agroforestry offers considerable benefits for long term agricultural sustainability with beneficial effects are as follows: (i) it increases diversity of on-farm trees, and crops, (ii) lands covered by trees could buffer the lands against the effects of climate variability, such as long period of drought, and dry spells, (iii) trees take up and store carbon at a faster rate than crops, and (iv) trees growing in dry season provide land coverage and shade for crops growing under trees and improve micro climate (Kohli et al 2008; Murthy et al 2013).

Agroforestry also plays an important ecological role in protecting soil from erosion, increasing nutrients in poor soils, and improving soil structures (Kang et al. 2000; Nair et al 1999; Schroeder 1995; Young 1990). It holds more water, and improves local environmental conditions for biodiversity, allowing plants to naturally grow, maintaining and increasing number of plant species. Biodiversity in agroforestry systems is typically higher than in conventional agricultural systems (Kohli et al 2008; Kalaba et al 2010; Moreno-Calles et 
al 2010). It incorporates at least several plant species into a given land area and creates a more complex habitat to support a wider variety of birds, insects, and other animals (Schroth et al 2004; Harvey et al 2007).

Socio economic benefits of agroforestry are (i) providing additional or off-season employment, (ii) providing food for cattle and providing useful products such as food, fuel, building poles, fodder or gum. Agroforestry systems can be advantageous over conventional agricultural and forest production methods through increasing productivity, economic benefits, social outcomes and the ecological goods and services (Pimentel et al 1999; Jose 2009). In dry area of West Nusa Tenggara as well as other eastern part of Indonesia, there are typical socio-economic and cultural factors affecting land degradation and risk to climate change, namely: (i) limited knowledge, lack of skills and innovative ability, (ii) low participation of local community, (iii) low income and capital, (iv) water shortage, (v) low soil fertility and management, (vi) insufficient local community empowerment, and (vii) lack of conservation practice by community (Ministry of Forestry 2002).

Biophysical conditions of dry land in eastern part of Indonesia, which are closely related to land degradation and its vulnerability to climate change are characterized by: (i) hilly topography, with slope of around $26-46 \%$, (ii) parent materials of soils are dominated by young sedimentary rocks and volcanic material which are sensitive to erosion, (iii) lands are mostly low vegetation coverage, low infiltration rate, and high runoff, (iv) long dry season (more than 6 dry months), and 3 to 4 months rainy season, with high erosivity rainfall and (v) land productivity is very low; needs high input to gain production (Ministry of Forestry 2002).

Imposing biopores in agroforestry cropping system has capacity to cope with those problems. Biopres in dry lands could capture more water and store it in soils as much as possible; improving soil infiltration rate and reducing runoff (Anggraeni et al 2013; Nieber et al. 2006). It would be a long term benefit of agrofrestry with biopores. Biopore has been widely applied in city area as part of drainage system to reduce flooding; infiltrating flood (standing water) into soils particularly in compact soils. Biopores could allow water to flows faster into soils and reduce runoff (Anggraeni et al 2013). Compost in the biopores is favorable for microorganism to grow and provide a good structure which is enable soil aeration to take places (Pagliai et al 2004; Prameswari et al 2014). In dry condition air can freely flows through macro pores which beneficial for aerobic organism to decompose organic matter. In other words, biopores system could improve biophysical condition of soils as well as soil fertility by decomposing organic matter and releasing plant nutrients. It is reasonable to apply biopores in agroforestry system along with organic management practice to enrich soil organic matter, reduce water loss by conserving water in soils.

This study explored to what extend the imposing biopores would achieve its role as an adaptation measure to climate variability. It was tested in a small scale agroforestry model located at semi arid tropic region of north Lombok, eastern Indonesia. Crop performance, e.g. trees and agricultural crops parameters, water balance, water use efficiency and climate variables were simultaneously measured in the field, as well as developing a scenario of possibility to scale up the model to broad areas in West Nusa Tenggara Province.

\section{Material and Method}

A participatory action research was conducted by meant o an experiment method through field experiments at three sites (Figure 1). Three groups of farmers were selected to involve in the field experiments. Each group had provided 0.2- 0.25 ha land to be developed into a small scale agroforestry. Other part of their land with similar size acted as a control treatment which was cultivated as ordinary practice. It followed pair paddock system where each group provided 0.2-0.25 ha land with scenario of agroforestry, and 0.2-0.25 ha land without scenario (as control). Each experiment was conducted on particular location (Figure 2) to represent the existing condition (typology) of agriculture lands at targeted areas, for instance: slope land (e.g. terraced land, undulating) at site-3, plate land at site-2, and coastal land (land close to beach) at site-1 (Figure 1, right).

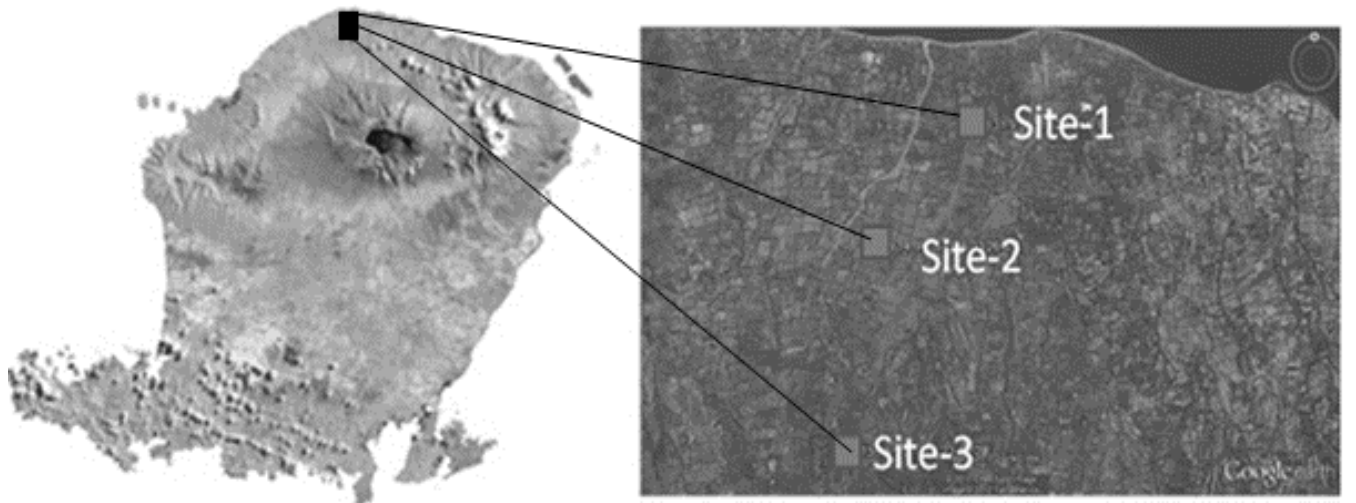

Figure 1. Field Experimental Sites at North Lombok (right), Lombok Island, Eastern Indonesia (left) The field experiments were conducted at Sukadane village, sub-district of Bayan, North Lombok. The 
geography coordinates of study sites were $08^{\circ} 12^{\prime}-08^{\circ} 27^{\prime} \mathrm{S}, 116^{\circ} 17^{\prime}-116^{\circ} 29 \mathrm{E}$. The study sites are part of Rinjani mountain's foot slope at north; steep to very steep slope, with soils order of mostly Inceptisols at upper parts and Entisols at lower parts. The elevation of the study sites range from $10 \mathrm{~m}$ to $300 \mathrm{~m}$ above sea level (asl). Climate of the study sites is classified as semi-arid tropic, with 9 months having less than $100 \mathrm{~mm}$ rainfall per month (dry months), and the rainy season is about 3 months, commonly starting in mid December to March. Primary data were collected by direct observation and secondary data were collected from relevant resources.

\subsection{Setting of Small Scale Agroforestry Model}

Selected land of 0.2-0-25 ha was reconstructed into a small scale agroforestry model with following steps:

- Biopores of diameter $10 \mathrm{~cm}$ and $20 \mathrm{~cm}$ depth were drilled by using a soil bore at row space of $0.5 \times 0.5$ $\mathrm{m}$ (Figure 2, right). Total biopores was 400 holes $/ 100 \mathrm{~m}^{2}$ or 8000 holes per 0.2 ha. Compost made of green manure (plant residue + dung, and poultry byproducts) was filled into the holes to make biopores. Rate of compost per hole was $2.35 \mathrm{~kg}$ (density $1.5 \mathrm{gram} / \mathrm{cm}^{3}$ ) of air dried weight or $18840 \mathrm{~kg}$ per 0.2 ha. It is equal to $12.56 \mathrm{~m}^{3}$ of air dried composts to refill 8000 holes in 0.2 ha.

- Biopores beneath trees were made on base of planting pits of $40 \mathrm{~cm} \mathrm{x} 40 \mathrm{~cm}$ x $40 \mathrm{~cm}$. There were 5 holes drilled with diameter of $10 \mathrm{~cm}$, and $40 \mathrm{~cm}$ depth on the base of the pits (Figure 2, right). Four biopores were placed at each corner of the pit and one hole in the center. Plantation of white teak was in alley cropping system, with row space of $10 \mathrm{~m}$ between lines or rows and $2 \mathrm{~m}$ in line (Figure 2, left). Direction of rows was east to west to allow sun rays reach spaces in between rows.

- Agriculture crops occupied space in between tree's rows of $10 \mathrm{~m}$ width (Figure 2, right). There were two planting carried out, i.e. agriculture crops, in wet season of 2011/2012 and 2012/2013.

- Planting grass and Sesbania sp, where in this scenario have two functions, namely: to reduce runoff and soil erosion (conservation purposes) and for feeding cattle. King grass was planted in stripping with row space of $20 \times 20 \mathrm{~cm}$ along land borders. Along stripping grass, Sesbania sp were planted at $2 \mathrm{~m}$ apart (Figure 2, right).
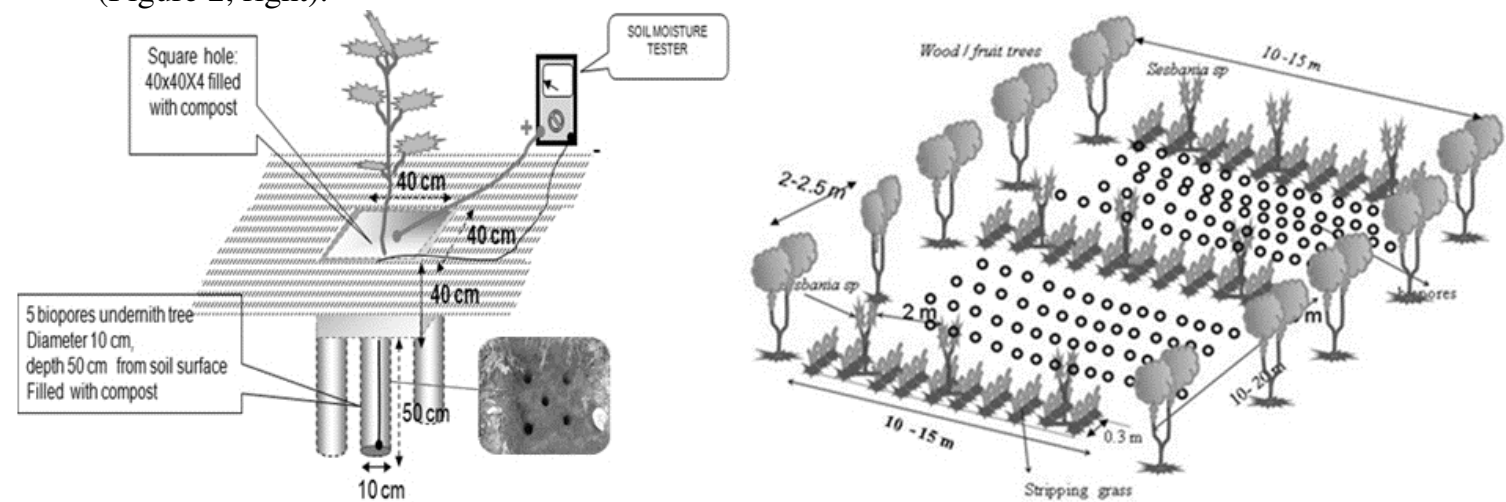

Figure 2. Imposed Biopores on Small Scale Agroforestry Model (right) and Biopores Underneath Trees (left)

\subsection{Parameters and Field Measurements}

- Rainfall. Daily rainfall was directly measured at location by using an ombrometer.

- Runoff (water out from plots). Runoff was measured by measuring water flow out from plot. Rain captured in $1 \times 1 \mathrm{~m}^{2}$ a pvc-frame was regularly measured at every rainfall event as volume of runoff. The runoff measurement was conducted at site-1 in rainy season of 2013.

- Soil erosion. Soil erosion was estimated from amount of soluble solid particles contained in runoff water. One litter of runoff water was evaporated in an oven at $100^{\circ} \mathrm{C}$. Dried particles were weighted to measure soils eroded from a particular plot.

- Potensial evapotranspiration (ETo). Potensial evapotranspiration (ETo) was predicted by applying Blaney Criddle method (SCS, 1970):

$\mathrm{ETo}=\mathrm{p}\left(0,46 t_{a}+8\right)$

Where: ETo is Potensial evapotranspirtion ( $\mathrm{cm} / \mathrm{month}), \boldsymbol{t}_{a}$ is average temperature $\left({ }^{\circ} \mathrm{C}\right)$, $p$ is percentage length of day time in a particular month depending on geographical position.

- Water balance. Water balance was calculated base on rainfall data $(\mathrm{R})$, irrigation from groundwater (if available) as water input; Runoff and ET (as water losses) and change in soil water storage $(\Delta \mathrm{S})$

- Temperature and Relative humidity. These parameter were measured daily by using dry and wet bulb thermometer installed nearby experimental plots.

- Vegetative and generative (yield) parameters. Data collection included: number of white teak successfully survived, plant height, and stem diameter which was measured at $1 / 3$ of its height above 
soil surface. These parameters were measured every three month interval, as follows: in first 3 month, 6 months, 9 months 12 months. Yield of cash crops was calculated from yield component of commodity or crop per unit area of land per harvesting.

- Carbon (C) in agroforestry system. The carbon monitoring system used in this study was developed by Winrock International's Carbon Monitoring Program to quantify the amount of $\mathrm{C}$ in land use systems using forest and agroforestry inventory principles and practices (MacDicken, 1997). Winrock's system quantifies $\mathrm{C}$ sequestered by measuring changes in four main carbon pools, namely: above-ground biomass, litter, herbaceous material and soil. To estimate biomass (kg) of above-ground vegetation after 12 months of age, the following general biomass regression equation (Brown, et al., 1997) was used for white teak.

$\exp \{-2.134+2.530 \times \ln (\mathrm{DBH})\}$

Where DBH is diameter of stem at breast-high. In this study, DBH was modified to stem diameter at $1 / 3$ of stem height from soil surface. Root biomass was estimated by taking $25 \%$ of above-ground biomass.

\section{Results}

\subsection{Growth Rate of White Teak}

White teak (Gmelina arborea) was well adapted to local climate condition of study sites. Other wood trees e.g. Mahagony (Swietenia mahagoni), Sengon (Albizzia falcataria) and fruit trees e.g. Rambutan (Nephelium lappaceum), Durian (Durio zhibethinus) Jackfruit (Artocarpus heterophyllus), Sapodilla (Manilkara zapota) were fail to survive in a critical period of first 6 months. Growth rate of white teak was estimated from the plant's height (Figure 3A, 3B and 3C) and stem diameter (Figure 4A, 4B and 4C). Both parameters were measured in three successive occasion, namely at 90 days after planting (first three months), 240 days ( 8 months) and 360 days (one year old).
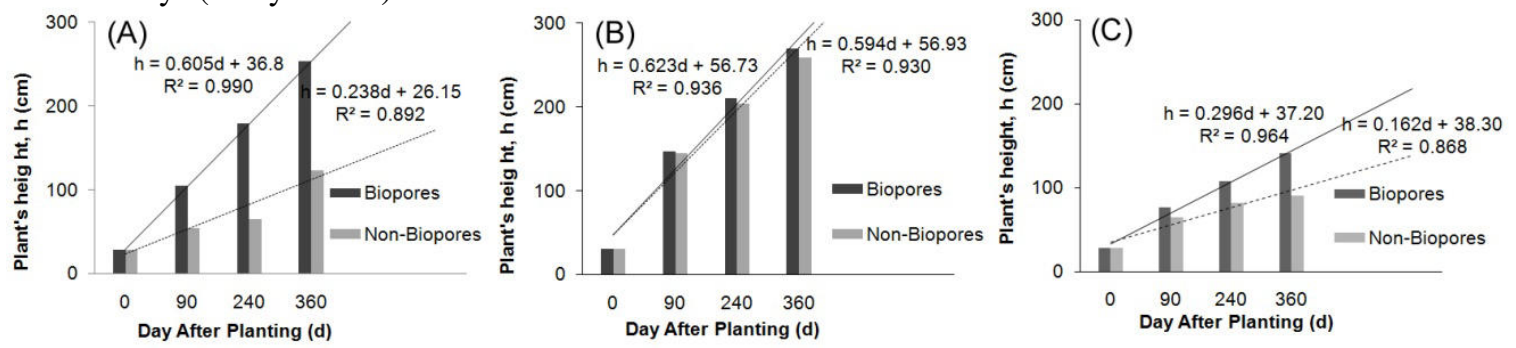

Figure 3. Vertical Growth of White Teak (Gmelina sp) on Biopores and Non Biopores: at Site-1 (A), Site-2 (B), and Site-3 (C)

As it is shown from Figure 3 that plant's height at biopores was higher than that at nonbiopores, with an exception at site 2 (Figures 3B) where plants for control treatment (without biopores) were given compost by farmers without permission from research team. It made the control treatment was relatively similar. Over all, growth rate of white teak on biopores was double than that on non biopores. The growth rate was $0.60 \mathrm{~cm}$ per day at biopores and $0.24 \mathrm{~cm}$ per day at non biopores at site- 1 . The rate at site- 3 was $0.3 \mathrm{~cm}$ per day for biopores and $0.16 \mathrm{~cm}$ per day for non biopores. While at site-2, the growth rate of white teak at biopores (treatment) and non biopores (control) was nearly the same, i.e. $0.62 \mathrm{~cm}$ per day and $0.59 \mathrm{~cm}$ per day respectively.

Figure 4 shows lateral development of stem diameter (DBH). Stem diameter was measured at one third of its total length from soil surface. As can be seen from the figures that white teak was well developed on biopores at all sites; DBH was wider at biopores than non biopores. The DBH at site-1 (Figure 4A) increased by $0.006 \mathrm{~cm}$ per day at biopores and $0.002 \mathrm{~cm}$ per day at non biopore. At site-3 (Figure 4C), the DBH increased by $0.004 \mathrm{~cm}$ per day and $0.001 \mathrm{~cm}$ per day at biopores and non biopores respectively. However, at site-2, development of stem diameter was quite similar between white teak growing on biopores than those growing on non biopores plus extra compost; developing rate of DBH was $0.007 \mathrm{~cm}$ per day at biopores and $0.005 \mathrm{~cm}$ per day at non biopores; biopores contributed to the stem diameter developing rate as much as 1.4 times. On average, white teaks growing at biopores were 2.8 times wider than those growing without biopores. 
$5(A)$

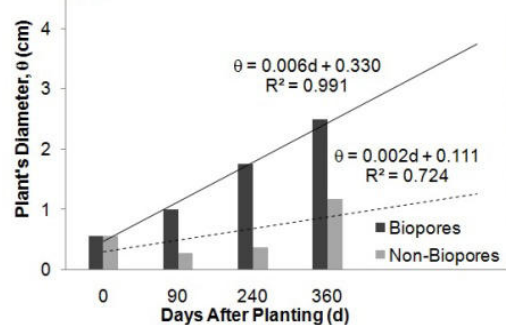

$5(B)$

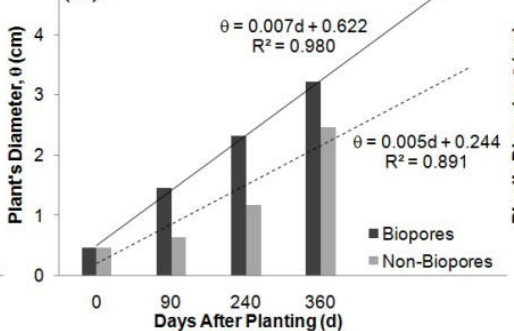

5 (C)

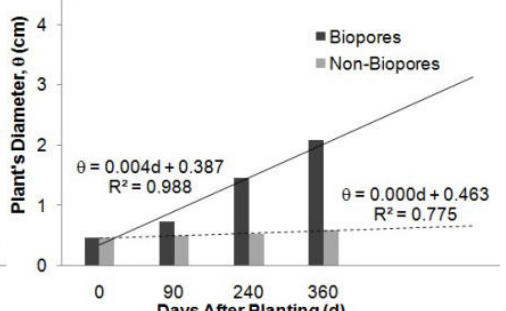

Figure 4. Diameter of White Teak (Gmelina sp) on Biopores and Non Biopores: Site-1 (A), Site-2 (B), and Site-3 (C)

\subsection{Agriculture Crops Performance}

First year crops (March to May 2012) were corn at site-1 and site-2, and ground nut at site-3. It can be seen from Figure 5A and 5B that corn growing at biopores site-1 produced 29\% more biomass than corn were growing at non biopore. At site-2, corn biomass at biopores was $43 \%$ heavier than that at non biopores. A similar trend was indicated by mass of dried biomass (Figure 5C and 5D, right bars). Dried biomass of corn growing on non biopores at site- 1 and site- 2 was $37 \%$ and $26 \%$ less than that on biopores respectively. Water contained in corn biomass was relatively similar between corn grew on biopores (67.5\% water content) and non biopores (69\% water content).

Corn grown on biopores at site-1 (Figure 5B) produced 11 ton fresh cob per hectare with 32\% water content, while corn grown on non biopores produced 8.53 ton per hectare with $33.5 \%$ water content. At site-2, corn on biopores produced 13.9 ton fresh cob with $40 \%$ water content, while on non biopores, it produced 7.9 ton fresh cob containing $24.5 \%$ water per hectare.
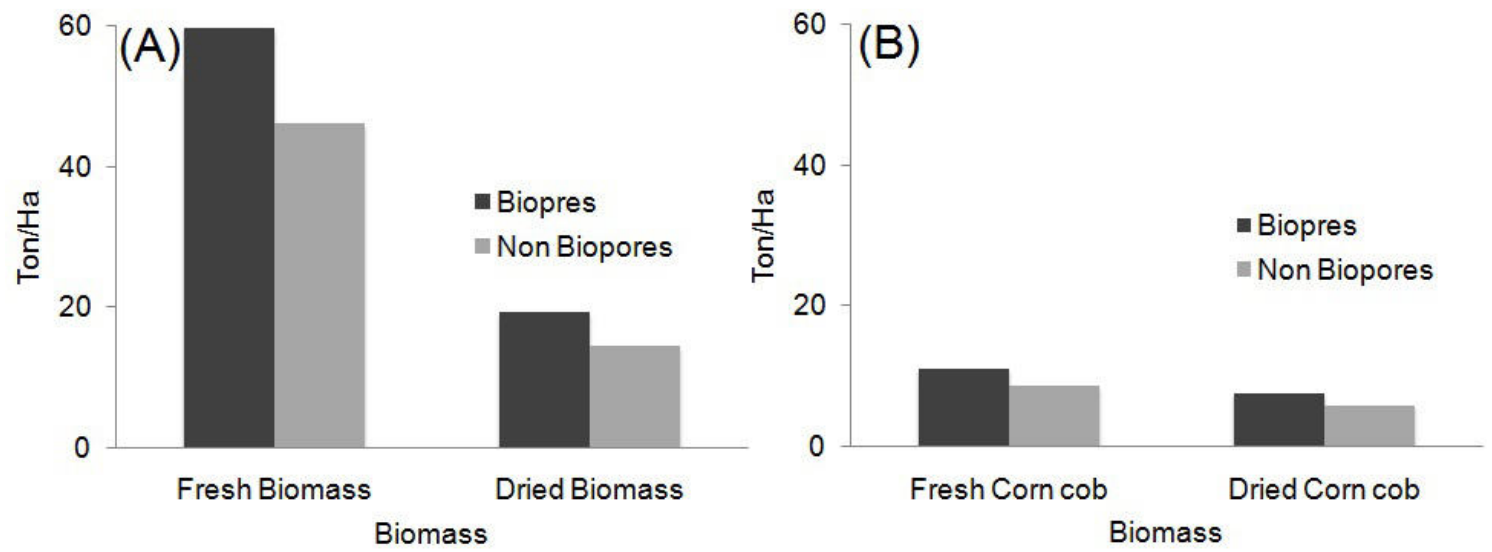

Figure 5. Comparison between Fresh Biomass (left bars), and Dried Biomass (right bars) of Corn Growing at Biopores and Non Biopores at Site-1 (A) and Comparison between Fresh Corn Cob (left bars), and Dried Corn Cob (right bars) of Corn Growing At Biopores and Non Biopores at Site-1(B)
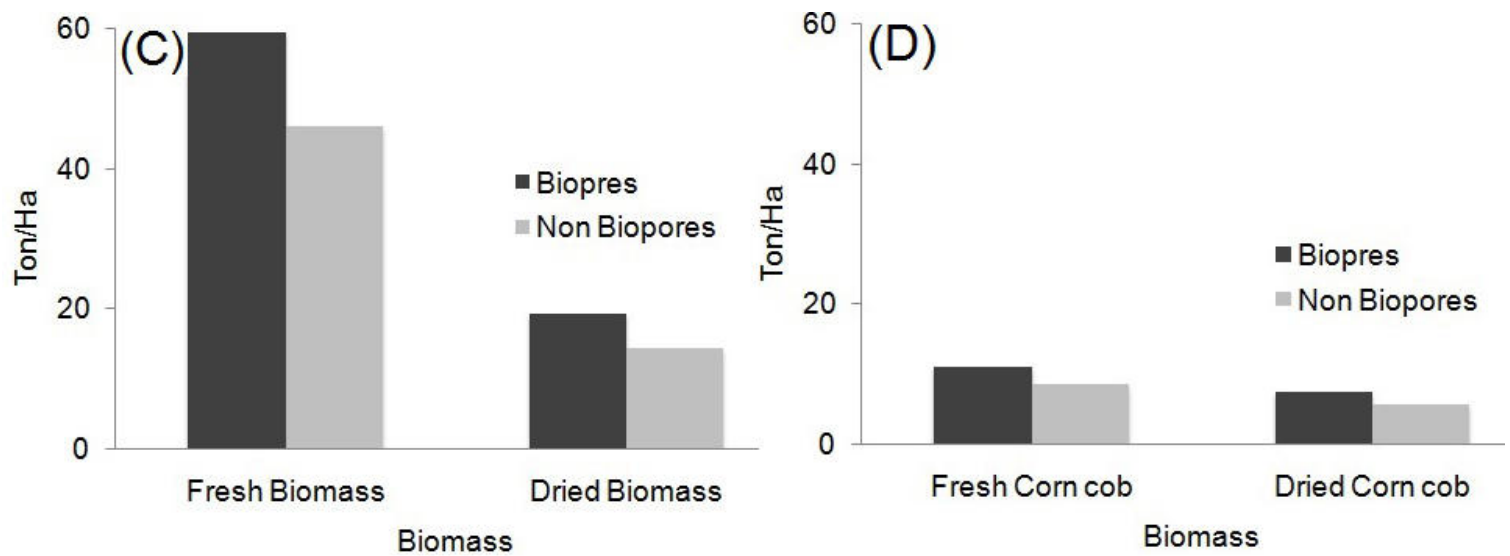

Figure 5. Comparison between Fresh Biomass (left bars), Dried Biomass (right bars) of Corn Growing at Biopores and Non Biopores at site-2 (C) and Comparison between Fresh Corn Cob (left bars), Dried Corn Cob (right bars) of Corn Growing at Biopores and Non Biopores at Site-2 (D) 
Ground nut was grown at site 3 in first year of project. Ground nut growing on biopores produced 21.3 tons of fresh biomass per hectare (Figure 6A). This figure was nearly doubled biomass of nut growing on non biopores (13.3 tons). Fresh biomass of nut growing on either biopores or non biopores contained 90-91\% water, and about one tenth of the biomass was dried biomass
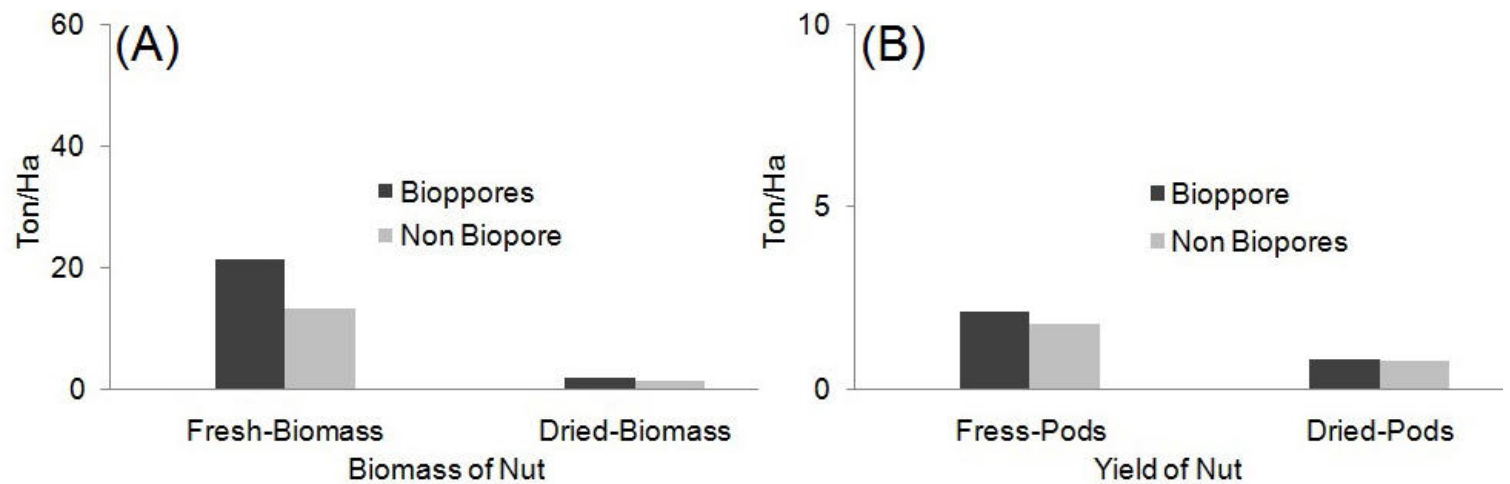

Figure 6. Comparison between Fresh Biomass (left bars), Dried Biomass (right bars) of Ground Nut Growing at Biopores and Non Biopores at Site-3 (A) and Comparison between Fresh Pods (left bars), Dried Pods (right bars) of Ground Nut Growing at Biopores and Non Biopores at Site-3 (B)

Yield of corn and nut grown in the first year project. It is clear from the Graph 7 that yield for corn (Figure 7, left bar for site 1; middle bar for site 2), and yield of nut (Figure 7 right bar) was higher on biopores than on non biopores. Average yield for corn on biopores reached 6.7 ton dried seed per ha. However, for corn growing on non biopores produced 4.7 ton dried seed per hectare on average. Yield for nut either at biopores or non biopores was relatively low. It had been expected to get higher yield on biopore rather than on non biopores, i.e. 0.46 ton dried seed per hectare on biopores compared to 0.36 tons per hectare on non biopores. It was 0.01 tons difference. It means that biopores had succeeded to improve vegetative growth of nut, but it had not improved the yield yet.

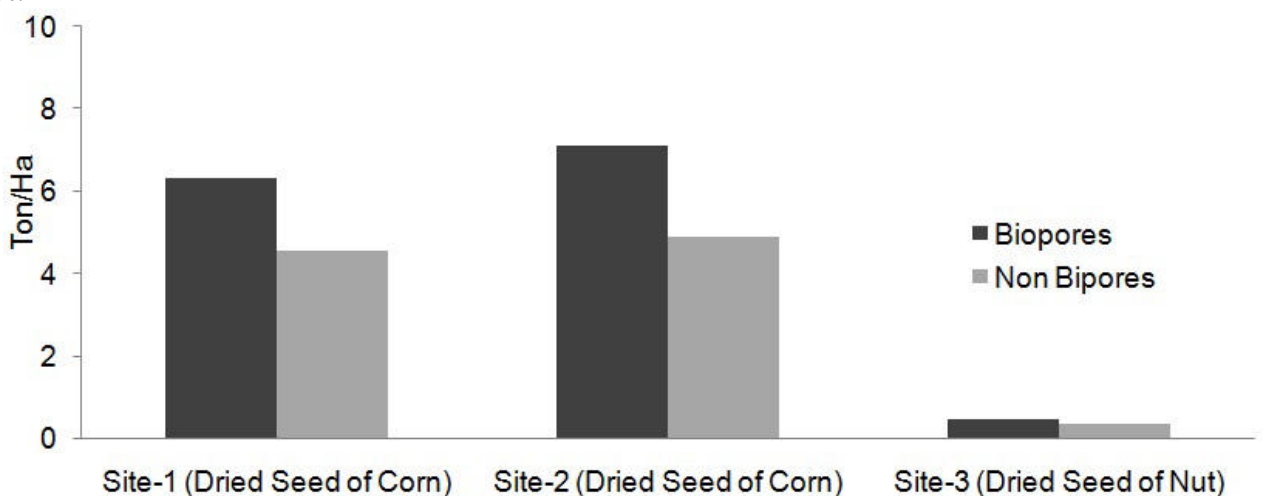

Figure 7. Comparison of Yield for Corn (at site-1 and site-2), Ground Nut (at site-3) Which Were Growing on Biopores and Non Biopores

Results of field experiments conducted in rainy season of 2012/2013 (January to March 2013) are presented on Figure 8. Crops planted varied at each sites; i.e. upland rice at site-1, and site-3, ground nut at site-2. As can be seen from Graph 8A that fresh biomass of nut produced on biopores was $8 \%$ higher than that of non biopores did. Fresh pods on biopores reached 2.43 tons per hectare, while on non biopore it was 0.5 ton less (Figure 8B). Dried pods on biopores was 0.1 ton higher than that on non biopores (Figure 8B). In other words, the yield of ground nut (dried seeds) could increase by 0.23 tons per hectare after one year of applying biopores in dry land of sandy soils at North Lombok (Figure 8C). 

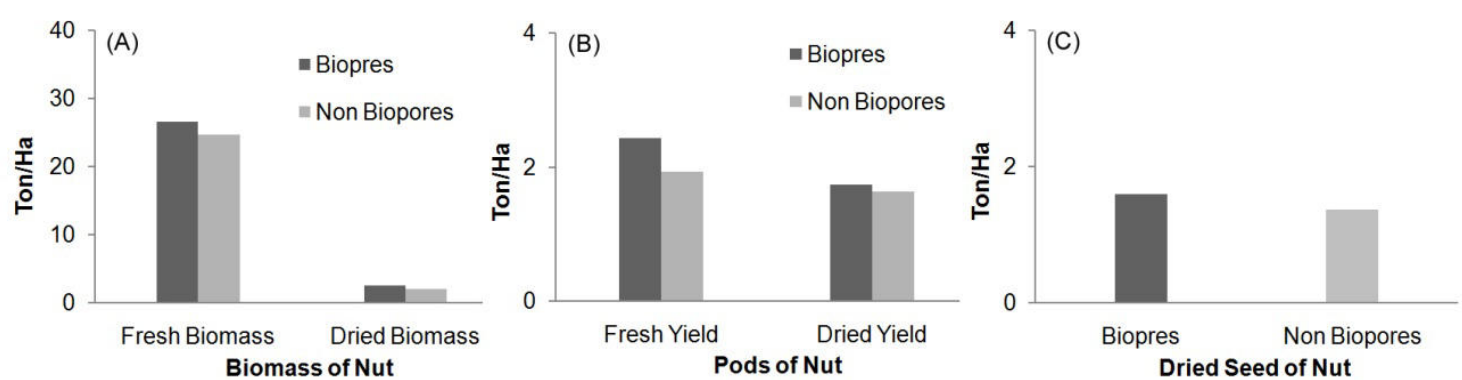

Figure 8. Parameter of Ground Nut in the $2^{\text {nd }}$ Year Growing on Biopores and Non Biopores at Site 2: Weight of Fresh and Dried Biomass (A), Weight of Fresh and Dried Pods (B), and Weight of Dried Seeds (C)

Adaptation of upland rice on biopores system was tested in the second growing seasons, namely at site- 1 in wet season of 2013 and at site-3 in wet season of 2013 (Figure 9). Figure 9 clearly indicates that upland rice had positively responded to biopores system. Upland rice grown in biopore system at site-3 in wet season of 2013 produced 3 tons/ha. It was 0.6 tons higher than that on non biopores where yield was 2.4 tons/ha. An extreme results was found at site-1where upland rice with similar variety was fail to produce yield on non biopores, while on biopores was 2.89 ton/ha.

The upland rice growing on non biopores was severely suffer from drought stress at its generative stage. This condition caused rice fail to produce seeds. On the other hand, rice growing on biopores produced 2.9 tons/ha under similar condition. This result suggests that biopores could save potential yield of local upland rice variety under deficit water in tropical semi arid region of north Lombok.

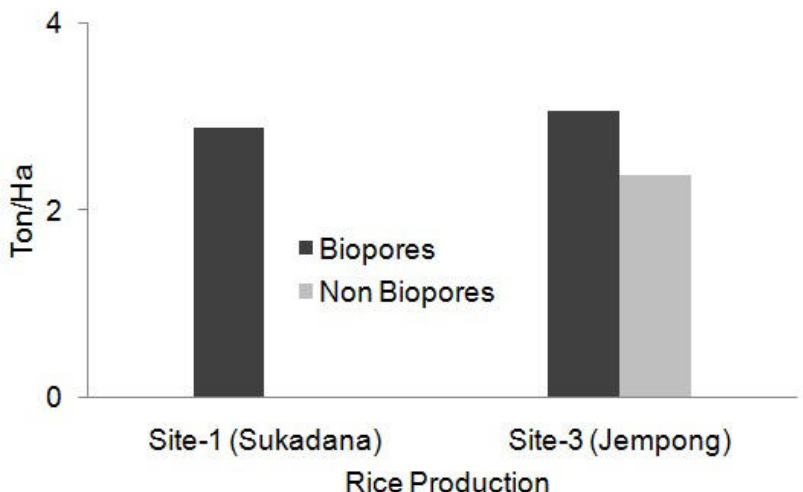

Figure 9. Upland Rice Yield as Response to Biopores System on Small Scale Agroforestry: Site-1 (left bar, and Site-3 (right bar)

\subsection{Water use eficiency in Dry Season}

Field experiment in dry season was focused on groundwater usage for secondary crop. Two techniques of water management was tested, namely surface irrigation on non biopores (farmer practice) and pouring on individual crop on biopores system. There were two field plots set up with size of $250 \mathrm{~m}^{2}$ where water melon (Citrullus lanatus) was planted with population of 146 plants. One plot was on biopores which was irrigated by mean of pouring technique and straw mulch. The other plot was on non biopore with surface irrigation without mulching. Pouring technique was carried out by individual watering; each individual plant was watered by $500 \mathrm{~cm}^{3}$ in every two days. Frequency of watering was 35 times in 80 days of growing period. Total water supplied through pouring system was 2,560 liter $\left(2.56 \mathrm{~m}^{3}\right)$ for all plants $\left(146\right.$ plants in $\left.250 \mathrm{~m}^{2}\right)$. Control treatment was farmer practice by mean of surface irrigation; water from groundwater source was delivered into land and recorded how much water was applied each time of irrigation. There was 4 times irrigation with interval irrigation of 20 days in 80 days. Total water was applied $30.66 \mathrm{~m}^{3}$ for area of $250 \mathrm{~m}^{2}$ with 146 plants.

Table 1. Amount of Groundwater Applied for Watering Water Melon in Dry Season

\begin{tabular}{|c|l|l|l|l|l|l|l|}
\hline \multicolumn{2}{|c|}{$\begin{array}{c}\text { Total water supplied } \\
\left(\mathrm{m}^{3} / 2500 \mathrm{~m}^{2}\right)\end{array}$} & \multicolumn{2}{c|}{ Yield $(\mathrm{kg})$} & \multicolumn{2}{c|}{$\begin{array}{c}\text { Water use Efficiency } \\
\left(\mathrm{kg} / \mathrm{m}^{3}\right)\end{array}$} & \multicolumn{2}{c|}{$\begin{array}{l}\text { Economic value of } \\
\text { groundwater Rp/liter }\end{array}$} \\
\hline $\begin{array}{l}\text { Surface } \\
\text { Irrigation }\end{array}$ & $\begin{array}{l}\text { Pouring } \\
\text { system }\end{array}$ & $\begin{array}{l}\text { Non- } \\
\text { Biopore }\end{array}$ & $\begin{array}{l}\text { Biopore+ } \\
\text { pouring }\end{array}$ & $\begin{array}{l}\text { Non- } \\
\text { Biopores }\end{array}$ & Biopores & $\begin{array}{l}\text { Non- } \\
\text { Biopores }\end{array}$ & Biopores \\
\hline 30.66 & 2.56 & 726.4 & 864.5 & 23.7 & 337.7 & 35.5 & 506.5 \\
\hline
\end{tabular}

Note : Frequency of application Surface Irrigation was 4 times with interval 20 days, Pouring system was 35 times with interval 2 days. 
Water use efficiency was calculated by dividing total yields (in $\mathrm{kg}$ ) of fruits and total water applied $\left(\mathrm{m}^{3}\right)$. It is clear from the data that pouring system on biopore land was 14 times more efficient in consuming water than surface irrigation did. It was due to high loss of water in surface irrigation, mainly through percolation, and evaporation. As a result, economic value of groundwater was very low by surface irrigation. The value was Rp. 35.5/liter by surface irrigation and Rp. 506.5 /liter by pouring system. Cost for pumping water to irrigate 146 melon by surface irrigation was Rp. 26,800 ( for $30.66 \mathrm{~m}^{3}$ water), while for pouring system on biopores the cost was Rp. 2,240 (for $2.56 \mathrm{~m}^{3}$ water) to irrigate the same amount of melon. It is clear from the figure that pouring system was about 15 times cheaper than surface irrigation.

\subsection{Runoff and Soil Loss (Dissolved Solid Particles)}

Runoff and dissolved solid particles (Figure 10) were directly measured in situ by constructing or installing one square meter of a pvc- tube with diameter $10 \mathrm{~cm}$. The one square meter perforated pvc frame was installed in between crop line of agriculture crops and under white teak of agroforestry. Measurements were carried out during rain event on $20^{\text {th }}, 21^{\text {st }}, 23^{\text {rd }}, 24^{\text {th }}$ of February and $2^{\text {nd }}, 3^{\text {rd }}, 4^{\text {th }}$ of March 2013.
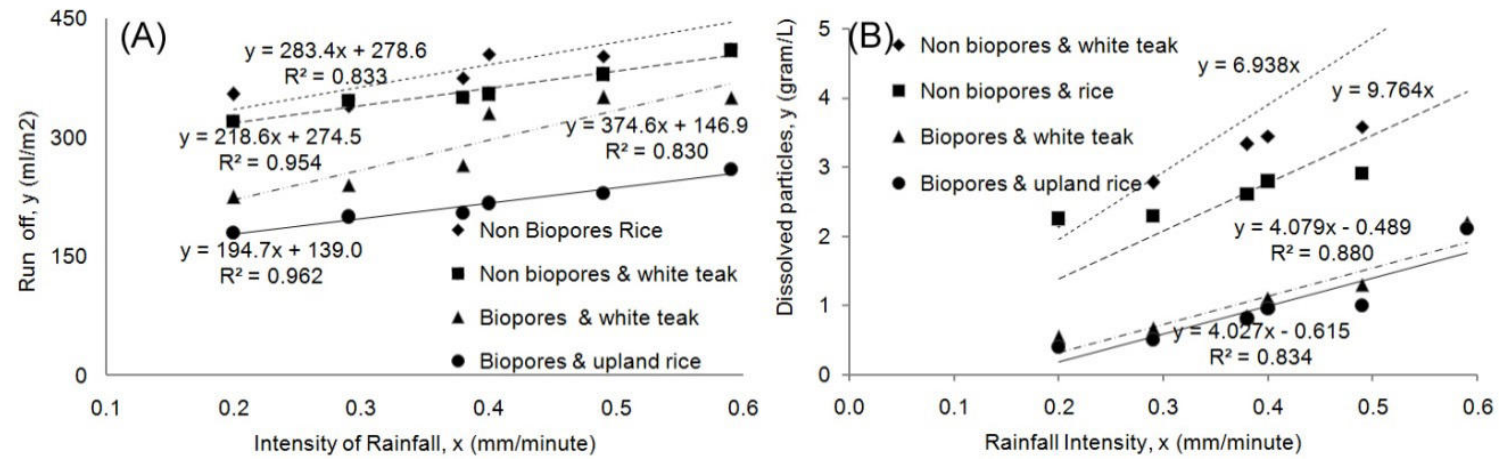

Figure 10. Relationship between Rainfall Intensity and Runoff (A) and Relationship between Rainfall Intensity and Dissolved Solid Particles (B)

It is shown on the Figure 10A that runoff increased as function of rain intensity. The highest runoff occurred on land without biopores planted with rice, while the lowest run off was on biopores land where upland rice were growing. Runoff increased by $195 \mathrm{ml} / \mathrm{m}^{2}$, and $219 \mathrm{ml} / \mathrm{m}^{2}$ per unit increase in rain intensity on biopores and non biopores with rice, respectively. A similar condition was found on biopores land planted with white teak where runoff was significantly reduced.

Figure 10B shows how biopores play role in diminishing solid dissolved particles in runoff water. Rate of soil loss from non biopore with upland rice reached 7 gram/liter runoff from one $\mathrm{m}^{2}$ area per unit increase of rain intensity ( $\mathrm{mm} / \mathrm{minute})$. On biopores, it decreased to 4 gram/liter runoff with similar unit increase of rain intensity ( $\mathrm{mm} / \mathrm{minute})$. In addition, biopores under white teak also reduced rate of soil loss. It was 4 gram/liter. $\mathrm{m}^{2}$ in biopores + white teak and 10 gram/liter. $\mathrm{m}^{2}$ in non biopores + white teak. The soil loss rate could be minimized by $43 \%$ per liter runoff by establishing biopores on upland rice, and $60 \%$ by providing biopores under trees (white teak). It means that biopores under trees were essential to reduce soil loss due to runoff.

Figure 11 shows comparation of crop cover effect on runoff and soil particle loss. It is clear from Figure 11a that there was less soil particles flashed out from biopores system compare to non biopore and bare soil. Dissolved solid particles on biopores were found if rainfall had reached commulative rainfall of $24.5 \mathrm{~mm}$, $36.5 \mathrm{~mm}$ or $46.3 \mathrm{~mm}$. First rain event caused high concentration of solid particles in runoff water.

Tipe of vegetation on either biopores or non biopores land gave different effect on run off. White teak of one year old growing on biopores could decrease runoff to a volume of 0.2 to $<0.4 \mathrm{liter} / \mathrm{m}^{2}$ within rain intensity of 0.2 to $0.6 \mathrm{~mm} /$ minute, while on non biopores volume of runoff ranged from $0.3-0.75 \mathrm{liter} / \mathrm{m}^{2}$ with the same rain intensity. In other words, biopores under white teak could reduce nearly a half of potential runoff from agroforestry system. 

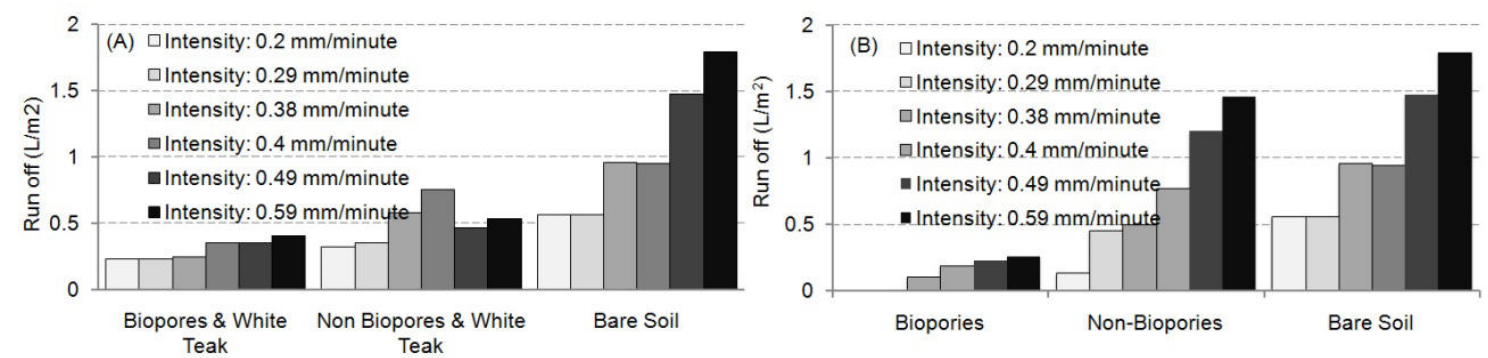

Figure 11. Comparison of Run off between Biopores \& White Teak, Non Biopores \& White Teak, and Bare Soil (A) and Comparison of Run off between Biopores \& Upland Rice, Non Biopores \& Upland Rice, and Bare Soil (B)

Growing upland rice on biopores (Figure 11) suppressed volume of runoff to a level less than $0.2 \mathrm{liter} / \mathrm{m}^{2}$ with similar intensity as for white teak. However, on non biopores run off was relatively high particularly when rain intensity reached $0.5-0.6 \mathrm{~mm} /$ minute. This phenomena suggest that biopores actually had a significant contribution in reducing runoff in agroforestry system at North Lombok. Agroforestry land without biopores would have potential runoff which was quite similar to bare soils. It means that soils in the study site was very sensitive to erosion if there was no vegetation or biopores. It might be due to unstructured soils (soil aggregate is very loose). Land covering with trees or agriculture crops was not enough to prevent run off in the system. Increasing capacity of soil infiltration by providing biopores must be taken into account to alleviate runoff. It seems that biopores had improved the infiltration capacity of soils as well as water holding capacity. As a result, runoff and soil loss had been significantly minimized.

\subsection{Carbon Stock}

Figure 12 shows amount of Carbon (C) was stored in a one year old white teak (Figure 12A) and total carbon stock in white teak at a small scale agroforestry with area of $2000 \mathrm{~m}^{2}$ (Figure 12B). White teak growing on biopores sequestrated a very high content of carbon compare to those which were growing on non biopores. The carbon stock in white teak was variation among sites; white teak at site-1 accumulated more carbon than at site 2 and 3. White teak growing at site-3 was under disturbance of cattle that fed on white teak in dry period. Therefore, growth of white teak was restricted. It was unexpected situation at site-3 when dry period occurred, the only white teak at experimental site looked green and was being attractive to cattle.
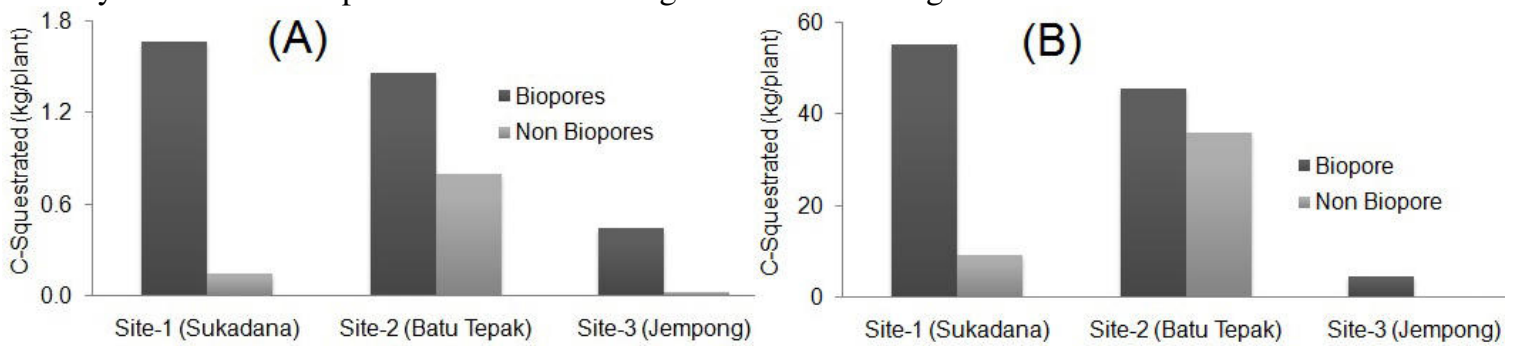

Figure 12. Carbon Stock in White Teak (Kg/plant) After One Year of Field Experiment (A) and Total Carbon Sequestrated in White Teak per $2000 \mathrm{~m}^{2}$ of Small Scale Agroforestry (B)

Cumulative carbon in small scale agroforestry with area of $2000 \mathrm{~m}^{2}$ varied among sites (Figure 12B). Exception for site- 3 where white teak was severe damaged by cattle. Site- 1 and site- 2 were well protected by farmers and there were not as dry as that at site-3. It is clear from the Figure 12B that there were $55.15 \mathrm{~kg}$, and $65 \mathrm{~kg}$ carbon produced by white teak growing on biopores within area of $2000 \mathrm{~m}^{2}$ for one year at site- 1 and site-2 respectively. White teak with biopores could produce 6 times more carbon than white teak without biopores. Data of white teak on non biopore at site- 2 was corrupted because of additional compost on to control treatment; farmer had deliberately put extra compost onto non biopore white teak to accelerate growth.

\subsection{Crop Water Requirement}

Water requirement was calculated for four main crops planted in experimental plots. Blaney Criddle method was used to predict potensial evapotranspiration (ETo) in the experimental sites. Ambient temperature and rainfall was directly measured during growing period of each crop. Crop coefficient $(k c)$ for each crop was quoted from literature and it was used to calculate crop evapotranspiration (ETc) per growing stage. The ETc of particular crop indicates consumptive use of water by each cropping system per season (Figure 13). 


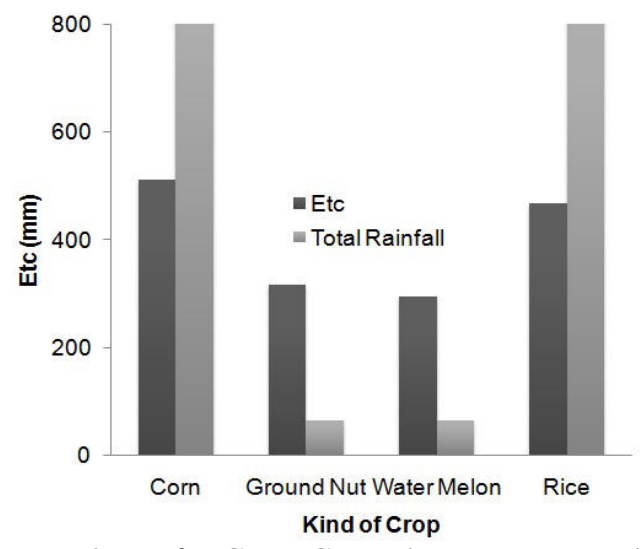

Figure 13. Water Balance for Corn, Ground Nut, Water Melon and Upland

Rice Growing at Field Plots of North Lombok

Corn and upland rice were growing in rainy season, i.e. corn was in February-April 2012, upland rice in rainy season of 2013 (January - April 2013). Ground nut and water melon were growing in dry season, i.e. ground nut in January to April 2012, water melon was in May to August 2012. There was a huge water excess in rainy season, when corn (2012) and upland rice (2013) were growing. The excess water was nearly double of actual water required by agriculture crops. Corn required $511 \mathrm{~mm}$ to complete its growth for 110 days, while cumulative rainfall within the period was $969 \mathrm{~mm}$ (surplus $458 \mathrm{~mm}$ ). Upland rice required $468 \mathrm{~mm}$, while water from rainfall was $860 \mathrm{~mm}$ (surplus $392 \mathrm{~mm}$ ). Surplus water during growing period would mean nothing if there was no effort to conserve it in soils or pond (reservoir). Here, biopores could play role to temporarily conserve water in soils to be used during dry spell period as well as to reduce water loss through runoff which was also washed away soil particles from land.

In dry season, condition was opposite, when available water was less than crop requirement. Water from rain was able to contribute of about $20 \%$ of crop's requirement, while $80 \%$ water deficit had to be supplied from groundwater irrigation. In this situation, dry season crops only relied on available water in soils or supplied from groundwater irrigation. Crops growing on biopores would take advantages to get more residual water conserved in the biopores. Otherwise, dry season crops would suffer from drought stress

\section{Discussion}

Agroforestry is becoming world wide agriculture system to optimize land use, and to combine agriculture crops and trees by intercropping or alley cropping (Nair 1993). It is suitable for crops that need shade, and silvopastural; growing fodder crops as forage for cattle under trees (Martínez et al 2014). Benefits of agroforestry system are that trees can capture nutrients deep in soils and return them on to soil surface during fallow period (dry season); recycling nutrients and organic matter in soils, sustaining biodiversity, activating soil microorganism and avoiding losses in production (Pimentel et al 1999). However, there are some restrictions in agroforestry system related to soil impedance effect, such as soil compaction was due to soil tillage practice which restricts root growth (Kozlowski 1999; Lipiec et al 2003; Ramazan et al 2012). Change in soil structure leading to susceptibility to nutrient leaching in soils, soil compaction, soil crusting, runoff and soil loss during heavy rain, soil aeration and infiltration (Pangliai et al 2004).

A field research regarding Climate Change Adaptation Program has been implemented at Sukedane Village, Sub District of Bayan, North Lombok as part of Kokok Putih main watershed in Lombok. It is located at northern foothill of Mt. Rinjani and becomes the most driest catchments where agroforestry system for cashew plantation and mangoes are distributed. Climate of the region is classified as semi arid tropic with 9 months dry and 3 months wet season.

To cope with those biophysical restrictions, particularly dealing with climate and soils, imposing biopores on a small scale agroforestry model had shown its beneficial effect on plant growth (white teak), yield of cash crops, upland rice, water use efficiency as well as reducing soil loss and increase C-sequestrated. Theoretical research question of "how to capture as much as possible water from rainfall and conserve it in soils as long as it could be? was mostly proved. Results had clearly shown that runoff decreased with more water was presumably conserved in soils (biopores), and reducing evaporation loss due to vegetation coverage. It has been scientifically proven that providing biopores plus compost in land has a capacity to cope with these parameters; namely, increasing infiltration rate, reducing runoff and storing water or keeping soil moisture for while in soils. In addition, reducing evaporation from open space was achieved by putting straw mulch and organic residues on soil surface. Agroforestry system would reduce evaporation when plant canopies have entirely covered lands or soil surface, which means that improving microclimate in the agroforestry system .

Finally, the goals of introducing biopores imposed in a small scale agrofoestry model has been 
achieved and scientifically proven in maintaining and enhancing quality of dry lands, without resulting negative impacts to environment. It would bring about economically beneficial in contributing to prosperity of local people, as well as developing community self reliance and their capacity in adapting to climate variability or future climate change

\section{Conclusion and Future Direction of Research and Development}

Base on results and general discussion, there has been drown conclusion as follows:

- Biopores on small scale agroforestry could improve agriculture crop performance; both vegetative growth and yields.

- Biopores under root zone of trees conserved soil moisture and made it available to plants during growing period as well as provided a better soil aeration within rhyzosphere which made roots more favorable during dry spell period.

- Biopores on sandy soil of semi arid region could potentially preserve excess water during rainy period and to be used in dry spell period or dry season

- Biopoeres imposed in Small scale agroforestry model had a potential capacity to reduce runoff and soil loss. The proposed model of small scale agroforestry imposed with biopores had been developed under a typical biophysical and climate condition at northern region of Lombok. It is required further research and development relate to following aspects of multy location demonstration plots with large scale. It would be better to include cropping pattern and cropping sequence to gain optimum yields with high economic benefit and sustainable land productivity.

\section{Acknowledgement}

It is to honestly acknowledge that extra effort carried out in two years field works would not be succeeded without supporting from the international partner, CSIRO with its supervision and guidance, as well as financial aid was provided by the Australian Government in collaboration with the State University of Mataram, Indonesia.

\section{References}

Acharya, A.K. \& Kafle, N. (2009), "Land Degradation Issues In Nepal And Its Management Through Agroforestry", The Journal of Agriculture and Environment 10, 115-123.

Alao, J.S., \& Shualbu, R.B. (2013), "Agroforestry Practices and Concepts in Sustainable Land Use Systems in Nigeria, Journal of Horticulture and Forestry 5(10), 156-159, DOI 10.5897/JHF11.055.

Anggraeni, M., Prayitno, G., Hariyani, S., \& Wahyuningtyas, A. (2013), "The Effectiveness of Bio-pore as an Alternative Eco drainage Technology to Control Flooding in Malang City (Case Study: Metro Sub-Watershed)", J Appl. Envron.Biol. Sci 3(2), 23-28.

Brown, S. (1997), "Estimating biomass and biomass change of tropical forests. A primer". FAO Forest Resources Assessment Publication, Roma, 134, 55p.

Easterling, W.E., P.K. Aggarwal, P. Batima, K.M. Brander, L. Erda, S.M. Howden, A. Kirilenko, J. Morton, J.F. Soussana, J. Schmidhuber and F.N. Tubiello, (2007), Food, fibre and forest products. Climate Change 2007: Impacts, Adaptation and Vulnerability. Contribution of Working Group II to the Fourth Assessment Report of the Intergovernmental Panel on Climate Change, M.L. Parry, O.F. Canziani, J.P. Palutikof, P.J. van der Linden and C.E. Hanson, Eds., Cambridge University Press, Cambridge, UK, 273-313.

Harvey, C.A. \& Villalobos, J.A.G. (2007), "Agroforestry System Conserve Species-rich but Modified Assemblagesof Tropical Birds and Bats", Biodiversity Conservation, 10.1007/s10531-007-9194-2

IPCC (2007), "Climate Change 2007. Synthesis Report Contribution of Working Group I, II, and III to the Fourth Assesment Report of the Intergovernmental Panel on Climate Change", IPCC. Genewa, Switzerland, $104 \mathrm{p}$.

Jose, S. (2009), "Agroforestry For Ecosystem Services and Environmental Benefits: An Overview", Agroforest Syst 76, 1-10, doi 10.1007/s10457-009-9229-7.

Kalaba, K.F., Chirwa, P.,Syampungani, S., \& Ajayi, C.O. (2010), "Contribution Of Agroforestry To Biodiversity And Livelihoods Improvement In Rural Communities Of Southern African Regions", In Tropical Rainforests And Agroforests Under Global Change, byTscharntke et al (editor), Environmental Science And Engineering, 461-476, Doi 10.1007/978-3-642-00493-3_22.

Kang, B.T. \& Akinnifesi, F.K. (2000), "Agroforestry As Alternative Land-Use Production Systems For The Tropics”, Natural Resources Forum 24, 137- 151.

Kohli, R.K., Singh, H.P., Batish, D.R., \& Jose, S. (2008), "Ecological Interactions in Agroforestry: An Overview", in Ecological Basis of Agroforestry (edited by Batish, D.R., Kohli, R.K., Jose, S., \& Singh, H.P), CRC Press, Taylor and Prancis Group, 1-14. 
Kozlowski, T.T. (1999), "Soil Compaction And Growth Of Woody Plants", Scan. J.For.Res 14, 596-619.

Kumar, B.M. (2013), "Mining Waste Contaminated Lands: An Uphill Battle For Improving Crop Productivity", Journal Of Degraded And Mining Lands Management 1(1), 43-50.

Lipiec, L., Medvedev, V.V., Birkas, M., Dumitru, E., Lyndina,T.E., Rousseva, S.\& Fulajtár, E. (2003), "Effect of soil compaction on root growth and crop yield in Central and Eastern Europe", International Agrophysics 17, 61-69.

MacDicken, K.G. (1997), "A Guide to Monitoring Carbon Storage in Forestry and Agroforestry Projects", Winrock Internationl Institute for Agricultural Development, 87p.

Martínez, J., Cajas, Y.S., León, J.D. \& Osorio, N.W. (2014), "Silvopastoral Systems Enhance Soil Quality in Grasslands of Colombia”, Applied and Environmental Soil Science, dx.doi.org/10.1155/2014/359736.

Ministry of Environment (2011), "Study on Risk and Adaptation to Climate Change in Lombok, West Nusa Tenggara", Indonesian Ministry of Environment, Jakarta, 81p.

Ministry of Forestry (2002), "Nasioanl Action Program For Combating Land Degradation in Indonesia", Ministery of Forestry, Jakarta, 28p.

Moreno-Calles, A., Casas, A., Blancas, J., Torres, I., Masera, O., Caballero, J., Garcia-Barrios, L., Perez-Negron, E., \& Rangel-Landa, S. (2010), "Agroforestry System and Biodiversity Conservation in Arid Zone: The Case of The Tehuacan Valley, Central Mexico", Agroforest Syst, doi 10.1007/s10457-010-9349-0.

Murthy, I.K., Gupta, M., Tomar, S., Munsi, M., Tiwari, R., Hegde, G.T. \& Ravindranath, N.H. (2013), "Carbon Sequestration Potential of Agroforestry Systems in India”, Journal Earth Science \& Climatic Change 4(1), doi:10.4172/2157-7617.1000131.

Nair, P.K.R. (1993), “An Introduction to Agroforestry”, Kluwer Academic Publisher, Nederland, 499p.

Nair, P.K.R., Buresh,R.J., Mugendi,D.N., \& Latt, C.R. (1999), "Nutrient Cycling in Tropical Agroforestry Systems:Myths and Science", in Agroforestry in Sustainable Agricultural Systems, by Buck, L.E., James P. Lassoie, J.P. \& Fernandes, E.C.M (editor), CRC Press, Florida.

Nieber, J.L., Tammo S. Steenhuis, T.S., Walter, T \& Bakker, M. (2006), "Enhancement Of Seepage And Lateral Preferential Flow By Biopores On Hillslopes". Biologia, Bratislava, 61/Suppl, 19, 225-228.

Pagliai, M., Vignozzi, N., \& Pellegrini, S. (2004), "Soil Structure and The Effect of Management Practices", Soil Tillage and Research 79, 131-143.

Pimentel, D., \& Wightman, A. (1999), "Nutrient Cycling in Tropical Agroforestry Systems:Myths and Science", in Agroforestry in Sustainable Agricultural Systems, by Buck, L.E., James P. Lassoie, J.P. \& Fernandes, E.C.M (editor), CRC Press, Florida.

Porter, J.R., L. Xie, A.J. Challinor, K. Cochrane, S.M. Howden, M.M. Iqbal, D.B. Lobell, \& Travasso, M.I. (2014), "Food security and food production systems". In: Climate Change 2014: Impacts, Adaptation, and Vulnerability. Part A: Global and Sectoral Aspects. Contribution of Working Group II to the Fifth Assessment Report of the Intergovernmental Panel on Climate Change [Field, C.B., V.R. Barros, D.J. Dokken, K.J. Mach, M.D. Mastrandrea, T.E. Bilir, M. Chatterjee, K.L. Ebi, Y.O. Estrada, R.C. Genova, B. Girma, E.S. Kissel, A.N. Levy, S. MacCracken, P.R. Mastrandrea, and L.L.White (eds.)]. Cambridge University Press, Cambridge, United Kingdom and New York, NY, USA, 485-533p.

Prameswari, D., Supriyanto, Saharjo, B.H., Wasis, B. \& Pamoengkas, P. (2014). "Utilization of Biopore Infiltration Hole and Cross Drain Technology to Improve Root Geometry and Mycorrhizal Colonization in Skidding Road", International Journal of Sciences: Basin and Applied Research 18 (1), 79-94.

Ramazan, M., Khan, G.D., Hanif, M. \& Ali, S. (2012), "Impact of Soil Compaction on Root Length and Yield of Corn (Zea mays) under Irrigated Condition”, Middle-East Journal of Scientific Research 11 (3): 382-385.

Schroeder, P. (1995), "Organic Matter Cycling By Tropical Agroforestry Systems: A Review", Journal Of Tropical Forest Science 7(3), 462 - 474.

Schroth, G., Harvey, C.A. \& Vincent, G. (2004), "Complex Agroforestry: Their Structure, Diversity, and Potenstial Role in Landscape Conservation", in Agroforestry and Biodiversity Conservation in Tropical Landscape, by Schroth, G., da Fonseca, G.A.B., Harvey, C.A., Gascon, C., Vasconcelos, H.L., \& Izac A.N. (editor), Island Press, Washington D.C, 227-260.

SCS. (1970), "Irrigation Water Requirements". Technical Release No. 21. USDA SoilConservation Service. Washington, DC.

Young A. (1990), “Agroforestry For Soil Conservation”, International Council For Research In Agroforestry, CAB International, 276p. 